TREES

\section{Colourful Street Trees}

In spring and summer the traveller in Egypt, tired of pyramids and lesser monuments, can feast his eyes on the splendid colours of the street trees. This, at least, is the impression given by a booklet called Street Trees in Egypt, by Dr Nabil El-Hadidi and Dr Loutfy Boulos and published by the herbarium of Cairo University. This guide, containing descriptions and drawings of fifty-two Egyptian cultivated trees of native and foreign origin, has been printed with the support of the authors and a jubilee fund collected by the UAR-Swedish Society in Stockholm, on the occasion of the seventieth birthday of Professor V. Täckholm, professor of systematic botany at Cairo.

In his foreword, Professor Täckholm remarks that Egypt is well known all over the world for its beautiful cultivated trees, and tourists always take away with them a memory of soft greenness sprinkled with gay colours. Until now, however, they have not, unless they were taxonomists with a rare breadth of knowledge, been able to identify these trees. Now, if they are prepared to search through fifty-two pages-there is no key in this guide-they can discover the names and origins of some of Egypt's cultivated trees.

Egypt, as a desert country, has few indigenous trees, but the mild climate is suitable for many exotic species, and there are trees from India, Malaya, Australia, tropical Africa, North and South America, China and Arabia. The streets of Egypt must certainly be brilliantly coloured in early spring with the bright red flowers of Bombax malabaricum, the silk-cotton tree; the purple, white and red flowers of Bauhinia variegata, the orchid tree with leaves resembling a camel's foot, and the crimson, pink or white flowers of Chorisia crispiflora. Later in spring there are the violet-blue flowers of Jacaranda acutifolia and from late spring until September Cassia fistula, golden shower, is in its full golden yellow glory. Tourists should beware of eating the berries of this tree, for they are reported to be laxative. Clearly, though, they should seize the chance of sitting under the bo-tree, Ficus religiosa, under which Buddha is said to have attained supreme knowledge. Ficus retusa, on the other hand, is best avoided-as the host of the scale insects which attack oranges and other fruits, it is considered a dangerous tree.

\section{SCIENCE AND SOCIETY}

\section{Problems of Responsibility}

\section{from a Correspondent}

A $T$ the beginning of November the West German branch of the international Society for Social Responsibility in Science ("Gesellschaft für Verantwortung in der Wissenschaft") held a conference entitled "Human Society in the View of Science". The aim was to discuss how scientists and technologists can contribute to the development of a healthy policy concerning the future of human society.

Introductory talks were given by a student of history, Mr G. Trautmann (Heidelberg University), and by a biologist, Professor H. Mohr of Freiburg University. Mr Trautmann called for an increasing democratization of the universities, allowing the students to take an active part in the reform of teaching and the choice of subjects of research. The close relationship between the universities and society would lead to further progress in social and economic democracy. Professor Mohr saw as the most important task of the responsible scientist his adherence to the strict ethical code of pure research which could serve as an example for a new ethics in politics; modern society is increasingly dominated by science and technology, and her problems can be solved only by planning on scientific principles.

The danger to man arising out of the irresponsible contamination of the biosphere was pointed out by a number of speakers. O. Haxel, professor of physics at Heidelberg University, gave data on the increasing contamination of the atmosphere by atomic bomb tests and nuclear reactors and mentioned in particular the marked increase of radioactive krypton. Dr W. Klein of the Institute for Ecological Chemistry at Birlinghoven described how chemical waste products appear in ever increasing quantities in many living organisms throughout the world. Insecticides and carcinogenic substances are brought down by rain; traces of fluor from hairspray propellants can be detected in the atmosphere, and the lead content in certain foodstuffs can be ten times higher than that in the air above traffic lanes.

F. Möller, professor of meteorology at the University of Munich, pointed out that the content of $\mathrm{CO}_{2}$ in the Earth's atmosphere had risen by 13 per cent from 1900 to 1960 through the burning of fossil fuels. He estimated that an increase of $\mathrm{CO}_{2}$ by 10 per cent would cause a rise of $0.3^{\circ} \mathrm{C}$ in temperature; this in turn would produce a corresponding increase in humidity and clouds, and a 10 per cent increase in low clouds would bring about a cooling of the Earth's surface by $8^{\circ} \mathrm{C}$. Professor H. J. Elster of the Department of Limnology, University of Freiburg, drew attention to the growing menace of infestation of lakes by algae, eaused by the presence of nitrates from over-fertilization of fields, and to the possibility that the new Dutch project for the disposal of waste into the North Sea might result in contamination up to the mouth of the Elbe.

Dr R. H. Fürth presented a paper on "The Role of Physical Models in Problems of Stability in Sociology" in which he pointed out the analogy between the behaviour of dense assemblies of particles and human communities, and suggested how certain results of the statistical mechanics of cooperative phenomena could be used as guiding principles for achieving a greater social stability.

A session of the conference was dedicated to problems of medicine, genetics and psychology in modern society. H. Schaefer, professor of physiology at Heidelberg University, in whose department the conference was held, drew attention to the fact that illness of the individual can be induced by the conditions of the society in which he lives, and that serious diseases can only be treated by means provided by that society; thus to keep healthy is not only a personal matter but also a matter of sociological ethics. Other speakers dealt with problems of overpopulation, genetic damage due to modern ways of life and the use of drugs, and the fact that serious disturbances in the social behaviour of adolescents and adults, just as in animals, can be induced by failure in the normal close relationship between mother and child in very early life. 